\title{
SOIL MINERALOGY AND ITS RELATIONSHIP WITH CACTI SPECIES IN SOUTHEASTERN CHIHUAHUA, MÉXICO
}

\section{MINERALOGÍA DEL SUELO Y SU RELACIÓN CON LAS ESPECIES DE CACTÁCEAS EN EL SURESTE DE CHIHUAHUA, MEXICO}

\author{
Toutcha Lebgue-Keleng ${ }^{1}$, Yadira E. Aviña-Domínguez ${ }^{2}$, Ricardo A. Soto-Cruz ${ }^{2}$, Miroslava Quiñonez-Martínez ${ }^{3}$, \\ Leonor Cortés-Palacios ${ }^{2}$, Alicia Melgoza-Castillos ${ }^{2}$, Carlos Morales-Nieto ${ }^{2}$, Cristina Vélez- Sanchez-Verin ${ }^{2}$ y \\ Salvador Balderrama-Castañeda ${ }^{2}$
}

\begin{abstract}
The relationship between minerals of soil and cacti may be an indicator of the distribution of these plants. The aim of this study was to determine the mineralogical composition of soils and its relationship with cacti in southeastern Chihuahua. Soil sampling was conducted in 2009 at 34 sites, samples were then analyzed by X-ray diffraction. Data were analyzed with ANOVA and Student $t$ test to determine the relation among types and percentage of minerals, soil types and cacti species. The laboratory analyses identified 15 minerals, quartz, calcite, albite and sanidine being the dominant and correlated with the presence of 32 cacti species, Opuntia engelmannii, $O$. imbricata and $O$. leptocaulis being the most frequent. There were more cacti on tuffs and limestone derived soils compared to basalts and granites derived soils. The Student's t test provided evidence $(p<0.05)$ of the significant relationship between sanidine with $O$. leptocaulis and $O$. macrocentra. Bayer's theorem indicated that calcite, quartz and sanidine were related to $O$. engelmannii (31.99 \%), O. macrocentra $(27.86 \%)$ and O. leptocaulis $(28.13 \%)$, respectively. Summarizing, sanidine, calcite and quartz were the minerals related to cacti; cacti were more diverse on tuff, rhyolite and limestone derived soils and scarce in basalt, alluvial and conglomerate derived soils.
\end{abstract}

Key words: Minerals, cacti, Chihuahua, $\mathrm{X}$ ray diffraction.

\section{Resumen}

La relación entre minerales del suelo y las especies de cactáceas puede ser un indicador de la distribución de estas plantas. El objetivo de este estudio fue determinar la composición mineralógica de los suelos y su relación con especies de cactus en el sureste de Chihuahua. El muestreo se llevó a cabo en el 2009. Las muestras de suelo fueron recolectadas en 34 sitios y se analizaron mediante difracción de rayos-X. Mediante ANOVA y la t de Student se probó la relación entre: tipos y porcentaje de minerales, tipos de suelo y cactus. Los resultados de laboratorio identificaron 15 minerales de los cuales cuarzo, calcita, albita y sanidina fueron dominantes y 32 especies de cactus, de las cuales Opuntia engelmannii, O. imbricata y $O$. leptocaulis fueron las más frecuentes. En cuanto a los tipos de suelo, hubo significativamente más cactus en suelos derivados de tobas y calizas en comparación con los derivados de basaltos y granitos. La prueba t de Student comprobó la relación significativa $(\mathrm{p}<0,05)$ entre sanidina y $O$. leptocaulis y $O$. macrocentra. El Teorema de Bayer indicó que la calcita, el cuarzo y la sanidina se relacionaron con O. engelmannii (31.99\%), O. macrocentra (27.86 \%) y O. leptocaulis (28.13\%), respectivamente. En conclusión, los minerales que tuvieron relación significativa con los cactus fueron sanidina, calcita y cuarzo; también fue significativa su relación con suelos derivados de toba, riolita y caliza y marcada su escasez en basaltos, suelos aluviales y conglomerados.

Palabras clave: Minerales, cactáceas, Chihuahua, difracción de rayos-X.

\section{Introduction.}

Cacti belong to a plant family native and endemic to the Americas (Bravo \& Scheinvar 2002) and are made up of about 120 genera and 1,500 to 1,600 species (Powell \& Weedin, 2004). Mexico has about 48 genera and 563 species, placing it with the greatest variety and species richness worldwide (Lopez et al., 2008 ), with $65 \%$ endemism. Specifically, the state of Chihuahua holds about $16 \%$ of them which accounts for 20 endemic species (Lebgue \& Quintana, 2010). Saldivia \& Rojas (2008) mentioned that thanks to their extensive and shallow root system, cacti have 
important roles in the ecosystems, such as mitigation of erosion and desertification. This is because they act as a shield, retaining soil particles and their roots have deciduous hairs that are incorporated as organic matter (Reyes \& Martinez, 2002).

Floral structures of cacti are adapted to be pollinated by different species as hummingbirds, sphinx (Dutrow \& Clark, 2010) and bats. Members of this family are adapted to the lack of water, which allows them to survive long periods of drought and also recover quickly, as they have the ability to store water in roots, stems and xylem, reducing its loss to minimum (Loza et al., 2003). Some species offer many benefits to humans since the fruits are edible and the stems are used as food and forage supplement due to the high percentages of water, minerals and vitamins as well as low levels of carbohydrate, protein and fat (Hernández et al., 2006).

Reyes \& Martinez (2002) explained that genetic, ecological, reproductive, and phytogeographical variables as well as nutritional requirements of cacti, are the major challenges that researchers on biodiversity are facing with. This statement is based on the fact that little information is known on these topics and it is not clear how these plants relate to the balance of minerals in soils and how it affects for an adequate development (Hernández et al., 2005). Due to its geographical diversity, Mexico has the largest variety of cacti species, specially, in the northern arid and semiarid ecosystems.

Saldivia \& Rojas (2008) documented the development of cacti on sandy and rocky derived soils. However, few studies in arid zones have associated soil factors with vegetation formations, thus making it relevant to identify the variables that affect and influence the composition, distribution and community structure of cacti (Teixeira et al., 2004). In other words, the relationship among minerals, chemical composition of rocks and abundance of plants is unknown in some regions (López et al., 2008). The study of the soil minerals in semi-arid and arid areas has received the least attention because soil science was founded and took rise in temperate and humid countries, containing minerals different to those found in ecosystems with low rainfall regime (Porta et al., 2008). The aim of this study was to determine the mineralogical composition of soils and to analyze their relationship with presence of species of cacti in the southeast of Chihuahua State, Mexico. The results of this study aspired to provide valuable information to explain the presence of some species of cacti and their dominance in soils widely distributed in desert ecosystems like those found in this study region.

\section{Materials and Methods.}

The study covered the municipalities of Camargo, Jiménez and Villa López (Figure 1), located in the

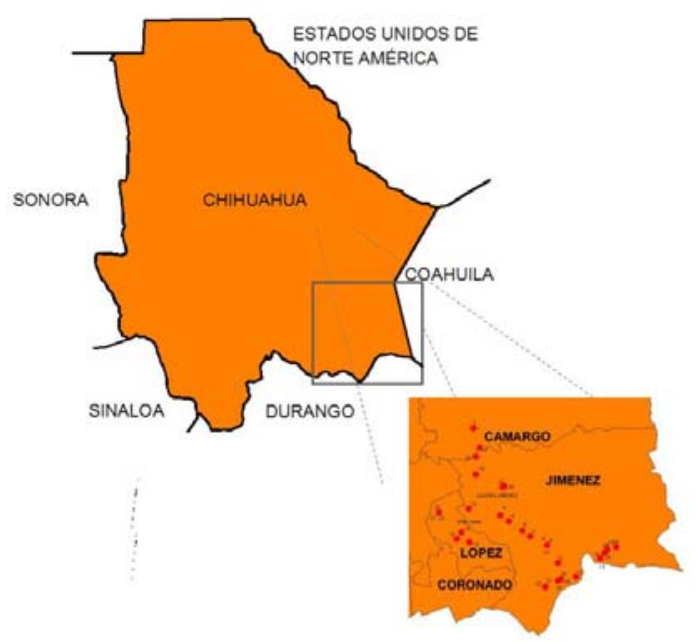

Figure 1. Localization of the study area.

southeast of the state of Chihuahua (between $27^{\circ} 39^{\prime} 50^{\prime \prime}$ and $26^{\circ} 34^{\prime} 50.15^{\prime \prime}$ Latitude N; $105^{\circ} 12^{\prime} 10$ .03 " and $104^{\circ} 5$ ' 46.51 "Longitude E) representing a total area of $13080 \mathrm{~km}^{2}$. The area is dominated by four vegetation types: two desert scrubs (creosote bush and lechuguilla associations) and two grassland communities (halophytic grassland and short grassland) (INEGI, 2009). The soil types are regosol, xerosols, Yermosols, castoñozems, fluvisol, feozems and cherozems but most are calcium or calcaric (INEGI, 1987).

The climate is dry, with average annual rainfall of 200-500 mm (summer), with an average annual temperature of $17.8^{\circ} \mathrm{C}$, the warmest month is July with $24{ }^{\circ} \mathrm{C}$ and the coldest, January with $10{ }^{\circ} \mathrm{C}$ (SIGCH, 2004).

Methods.

The survey was carried out from February to May 2009. Random sampling was conducted in 34 sites, extracting soil samples from a distance of not more than $1 \mathrm{~m}$ from a cactus plant found and at depths no greater than $30 \mathrm{~cm}$. Material obtained (about $1 \mathrm{~kg}$ of material per sample) from excavation profile was placed in a plastic bag and marking it with site number, location, date, and depth of the excavation (Tarbuck \& Lutgens, 2008). Within each site, soil types were recorded together with all the species of cacti present.

The preparation and analyses of samples were performed at the Research Center for Advanced Materials S. C. (CIMAV) of the city of Chihuahua. First, the samples were passed through a \# 14 mesh to reduce the clay lumps and to obtain fine soil particles. These fine particles were homogenized by placing them on a rubber film into circular cakes which were later divided into four parts by two perpendicular 
diagonal lines. Two samples were taken from opposite sides, and the remaining two were "discarded". This operation was repeated five times until obtaining a reduced and representative sample. The remaining soil material was packed in a plastic bag $(10 \times 15 \mathrm{~cm})$. From the representative sample, a small portion (about 3 gr) was taken and was later ground in an Agata mortar giving it a powder consistency; and it was this powdered material that was run through the X'Pert PRO MPD diffractometer Panalytical with the computer program X'Pert Data Collector, with the following specifications: $40 \mathrm{kV}, 35 \mathrm{~mA}, 3$ - to $85^{\circ} 2$ theta sweep, $0.0167^{\circ}$ step time of $50 \mathrm{~s} /$ step $4 \mathrm{~s}$ rotation / revolution nickel filter and mask 20. This same analysis was repeated for all 34 samples.

\section{Results and discussion.}

After the analyses, the soil minerals found were: quartz, calcite, sanidine, albite, nontronite, muscovite, montmorillonite, hematite, faujasite, dolomite, microcline, anorthite, anorthoclase, clinochlore and epidote. The most abundant were quartz, calcite with 25 to $30 \%$ each, albite $18.5 \%$, sanidine $9.5 \%$, silicon 13 to $50 \%$, calcium 3 to $25 \%$, aluminum 3 to $25 \%$ and the rest of minerals registered from 0.3 to $3 \%$ in the overall composition of the sites.

In this survey, 32 species of cacti (Table 1) were identified, the most common being Opuntia engelmannii and O. macrocentra, which occurred in all soil types and were widely distributed, adapted to arid drought conditions with poor vegetation cover, subject to erosion (Reynolds \& Arias, 2003). This information coincides with that reported by Lebgue \& Quintana (2010) who found these species widely distributed in the state of Chihuahua, together with $O$. imbricata var. arborescens and O. leptocaulis which happened to be found with high frequencies in sampled sites, but with zero presence in Quaternary andesitic rocks and granite.

Analysis of cacti distribution by soil type, identified that tuff and limestone had the highest

Table 1. Cacti species found in the study area.

\begin{tabular}{ll}
\hline \multicolumn{2}{c}{ Cactáceas } \\
\hline Coryphantha echinus var. echinus & Glandulicactus uncinatus var. uncinatus \\
Coryphantha echinus var. robusta & Lophophora williamsii \\
Coryphantha macromeris & Mammillaria heyderi \\
Coryphantha poselgeriana & Mammillaria lasiacantha \\
Coryphantha scheeri var scheeri & Mammillaria pottsii \\
Coryphantha sneedii var. sneedii & Opuntia azuria \\
Coryphantha tuberculosa & Opuntia engelmannii var. engelmannii \\
Coryphantha ramillosa & Opuntia imbricata var. arborescens \\
Echinocereus dasyacanthus & Opuntia kleiniae \\
Echinocereus enneacanthus var enneacanthus & Opuntia leptocaulis \\
Echinocereus pectinatus & Opuntia macrocentra \\
Echinocereus stramineus & Opuntia phaecantha \\
Echinomastus unguispinus var. unguispinus & Opuntia rufida \\
Epithelantha bookei & Opuntia schottii var. schottii \\
Epithelantha micromeris & Thelocactus bicolor var. bicolor \\
Ferocactus hamatacanthus & \\
\hline
\end{tabular}

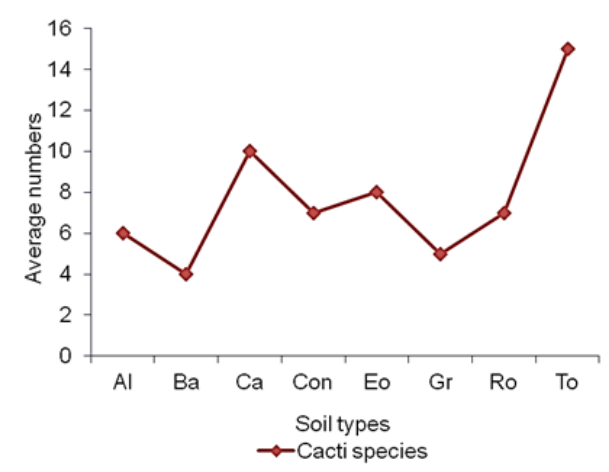

Figure 2. Average number of cacti species per soil type. $\mathrm{Al}=$ Quaternary alluvial, $\mathrm{Ba}=$ superior Tertiary Basalt, $\mathrm{Ca}=$ Lower Cretaceous Limestone, Con $=$ upper Tertiary conglomerate, Eo $=$ Wind quaternary, $\mathrm{Ga}=$ Tertiary granite, $\mathrm{Ro}$ $=$ Quaternary andesitic rock and To $=$ inferior Tertiary rhyolitic tuff.

average of cacti with 15 and 10 species respectively, while basalt and granite presented few species, 4 and 5 , respectively (Figure 2).

To determine whether the most abundant minerals affect the presence of cacti, the mean comparison test was used with the Student's t test, resulting to be significant $(p<0.05)$ the relationship between the presence of sanidine and Opuntia leptocaulis and $O$. macrocentra. With the general linear model, it was found that the interaction of the two major cacti species (O. engelmannii and $O$. macrocentra) was highly significant ( $<<0.0262)$; combinations $O$. imbricata var. arborescens and O. leptocaulis had a highly significant relationship $(\mathrm{p}<0.0086)$, and the same relation was observed in the case of $O$. engelmannii with $O$. leptocaulis $(\mathrm{p}<0.0052)$.

The ANOVA test provided evidence of the relationship between calcite and soil type $(p<0.05)$. In the analysis by comparison of means using the Tukey test, no atypical values for any type of soil were found; however, the conglomerate showed greater variability, followed by limestone and basalt (Figure 3).

The correlation analysis detected a relationship between calcite and albite of -0.64 , and -0.61 for quartz and calcite. The confidence intervals were obtained for 


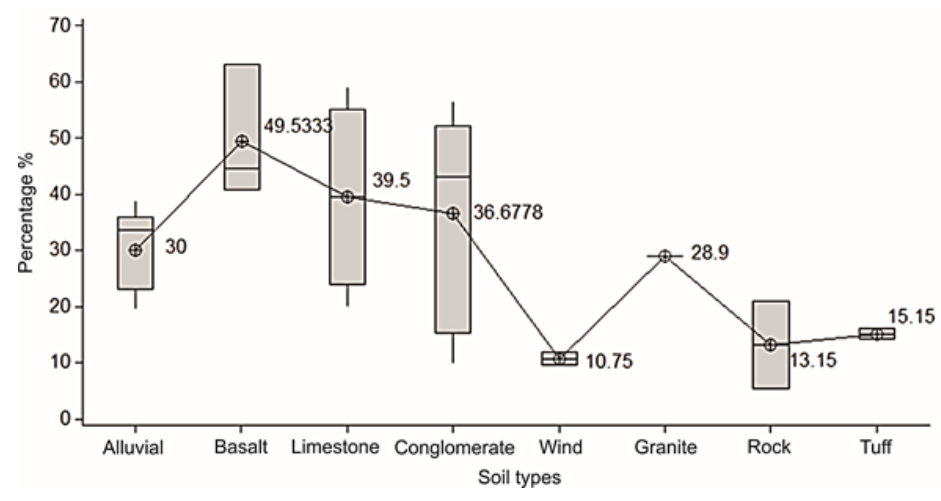

Figure 3. Comparison of means using the Tukey test among soil types.

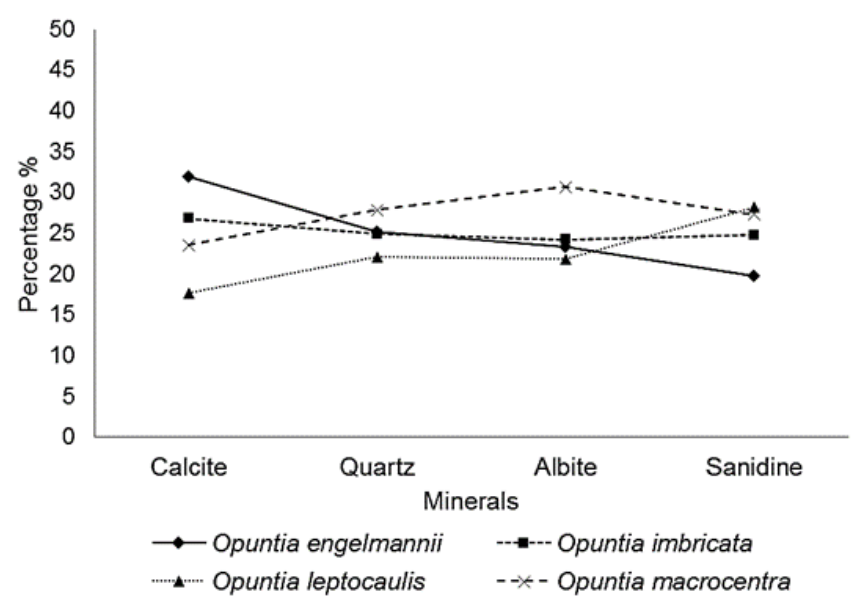

Figure 4. Probabilities of the presence of cacti with minerals.

$100 \%$. The cacti, all together, have a dependency on quartz, calcite, albite and sanidine, higher than 17 $\%$. O. engelmannii has $31.99 \%$ dependency on calcite (the highest value found in the study); $O$. macrocentra, $27.86 \%$ on quartz and $30.65 \%$ on albite. O. leptocaulis presented a $28.13 \%$ on sanidine, and $O$. imbricata is very stable with percentages ranging from $24.22 \%$ to $26.83 \%$ (Figure 4) on these minerals.

Finally, the cacti, Lophophora williamsii (peyote), Coryphantha ramillosa and Epithelantha micromeris were found only in poorly developed soils with calcareous "old" rocks composed mainly of calcium carbonate and silica, derived from limestone flint. Soil types with greater diversity of cacti were tuff, rhyolite and limestone.

\section{Conclusions and recommendations.}

The presence of cacti in the study region is determined by soils where minerals of calcite, quartz, albite and sanidine predominate considering its high percentage in the mineralogical composition of the soil samples analyzed.

Sanidine - O. leptocaulis and $O$. macrocentra relationship was the most common and as resulted in this

each element through the means and standard error of the main minerals: these intervals were for albite $16.42 \pm \beta \pm 20.5$; calcite $34.06 \pm \beta \pm 28.76$; quartz $25.14 \pm \beta \pm 27.4$ and $8.26 \pm \beta \pm 10.74$ for sanidine, concluding that there is uniformity in the sample data.

When correlating the three municipalities with minerals with higher percentages, a high negative correlation in the municipalities of Camargo and Jimenez was detected for calcite, but high positive relationship in these two municipalities with albite and sanidine was found (Table 2).

Comparison of means test was used to determine whether the four main minerals affect the presence of the four major cacti with the Student's t test, sufficient evidence was found $(p<0.05)$ for the relationship between sanidine and $\mathrm{O}$. leptocaulis and O. macrocentra.

To evaluate the probability of mineral dependency on cacti and vice versa, Bayer's theorem was used, and the percentages were selected to obtain the most important and the sum is taken as equal to study, these two species are dependent on the presence of sanidine in the soil, and thus concluding that wherever there is presence of these cacti, there must be a good percentage of that mineral in the sub soil. On the other hand, the calcite has an inverse relationship with sanidine, meaning that the higher the

Table 2. Correlations of the main minerals per municipality.

\begin{tabular}{|c|c|c|c|c|}
\hline & & Camargo & Jiménez & V. López \\
\hline & Camargo & 1 & & \\
\hline Cuarzo & Jiménez & 0.0763 & 1 & \\
\hline & V. López & 0.3763 & 0.0135 & 1 \\
\hline & Camargo & 1 & & \\
\hline Calcita & Jiménez & $-0.9068 *$ & 1 & \\
\hline & V. López & 0.4642 & -0.3181 & 1 \\
\hline & Camargo & 1 & & \\
\hline Albita & Jiménez & $0.9737 *$ & 1 & \\
\hline & V. López & 0.1664 & 0.5195 & 1 \\
\hline & Camargo & 1 & & \\
\hline Sanidina & Jiménez & $0.9921 *$ & 1 & \\
\hline & V. López & 0.5715 & 0.2959 & 1 \\
\hline
\end{tabular}


soil calcite the less the presence of sanidine.

Finally, it is recommendable to carry out further similar studies in other areas of the state to generate more databases that show patterns of the relationships of soil mineralogy with cacti.

Acknowledgements: This study would not be possible if it wasn't for the funds provided by FomixConacyt, Gobierno de Estado de Chihuahua and the help received from Universidad Autónoma de Chihuahua for transportation to the study region.

\section{Literature Cited.}

Bravo H.H. \& Scheinvar L. 2002. El interesante mundo de las cactáceas. Fondo de Cultura Económica. México.

Dutrow B. \& Clark M. 2010. Geochemical Instrumentation and Analysis. X-ray Powder Diffraction (XRD). Publicado por Science education resource center at carleton college. http://serc.carleton.edu. Consultado Feb. 20, 2010.

Edwards J.E., Nyffeler R. \& Donoghue M.J. 2005. Basal cactus phylogeny: implications of Pereskia (Cactaceae) paraphyly for the transition to the cactus life form. American Journal of Botany. 92:1177-1188 p.

Hernández A., Toledo P. S., Marí A.J., Hondal N. L. \& García M. V. 2005. La familia Cactaceae en la provincia Sancti Spíritus, Cuba Central. Rev. Jardín. 5:95-98 p.

Hernández H.M., Gómez H.C. \& Goettsch B. 2004. Checklist of Chihuahuan desert Cactaceae. Harvard Papers in Botany. 9:51-68 p.

Hernández J.A., Ascanio M.O., Morales D.M., Bojórquez I.J., García N.E. \& García J.D. 2006. El suelo: fundamentos sobre su formación los cambios globales. $1^{\text {era }}$ ed. Editorial Universidad Autónoma de Nayarit. México.

INEGI.1987. Instituto Nacional de Estadística Geografía e Información. Carta Geológica de Hidalgo del Parral G13-5, escala 1:250, 000 .
INEGI. 2009. Instituto Nacional de Estadística Geografía e Informática. http://mapserver.inegi.org.mx. Consultado en mayo 2 de 2009.

Lebgue K.T. \& Quintana G. M. 2010. Las Cactáceas de Chihuahua: tesoro estatal en peligro de extinción.1era ed. Impresos Grafimagen. Chihuahua.

López R.B., Bashan Y., Bacilio M. \& De la Cruz-Agüero G. 2008. Rock-colonizing plants: abundance of the endemic cactus Mammillaria fraileana related to rock type in the southern Sonoran Desert. Plant Ecol. 201:575-588 p.

Loza C.S, Terrazas T., López L.M. \& Trejo C. 2003. Características morfo-anatómicas y metabolismo fotosintético en plántulas de Stenocereus queretaroensis (Cacteceae): Su significado adaptativo. INCI .28:83-89 p.

Porta C.J., López-Acevedo M.R. \& Poch R.M. 2008. Introducción a la edafología: uso y protección del suelo. $1^{\text {era }}$ ed. Editorial Mundi-Prensa. España.

Powell A.M. \& Weedin J.F. 2004. Cacti of the Trans-Pecos and Adjacent Areas. Texas Tech University Press. Lubbock, Texas.

Reyes M.J.M. \& Martínez M.D. 2002. El futuro de la vegetación. Ciencia y cultura. 9:45 p.

Reynolds S.G. \& Arias R.E. 2003. El nopal (Opuntia spp.) como forraje. http://www4.fao.org. Consultado Nov. $18,2010$.

Saldivia P. \& Rojas G. 2008. New records and antecedents of the Cactaceae family to chile in aisen region. GayanaBot. (2):198-208 p.

SIGCH. 2004. Sistema de Información Geográfica del Estado de Chihuahua. 1era ed. Editorial Talleres gráficos del INEGI. Aguascalientes, Aguascalientes.

Tarbuck J.E. \& Lutgens F.K. 2008. Ciencias de la tierra: Introducción a la geologia física. 8va ed. Editorial Person Prentice Hall. España.

Teixeira R.V., Castro V., Ceroni A. \& Eyzaguirre P.R. 2004. Diversidad y densidad de la comunidad de cactáceas en el cerro Umarcata y Quebrada Orobel en el valle del río Chillón (Lima) y sus relaciones con los factores edáficos. Ecología Aplicada. 3:1-8 p.

\footnotetext{
${ }^{1}$ Facultad de Zootecnia y Ecología, Universidad Autónoma de Chihuahua, México. Correo electrónico: tlebgue@uach.mx

${ }^{2}$ Facultad de Zootecnia y Ecología, Universidad Autónoma de Chihuahua, México.

${ }^{3}$ Instituto de Ciencias Biomédicas, Universidad Autónoma de Ciudad Juárez, México.
} 